\title{
Peptide Vaccines for Leishmaniasis
}

\author{
Rory C. F. De Brito ${ }^{1,2}$, Jamille M. De O. Cardoso ${ }^{2}$, Levi E. S. Reis ${ }^{1,2}$, Joao F. Vieira ${ }^{2}$, \\ Fernando A. S. Mathias ${ }^{2}$, Bruno M. Roatt ${ }^{1,2,3}$, Rodrigo Dian D. O. Aguiar-Soares ${ }^{2}$, \\ Jeronimo C. Ruiz ${ }^{4,5}$, Daniela de M. Resende ${ }^{4,5}$ and Alexandre B. Reis ${ }^{1,2,3 *}$
}

OPEN ACCESS

Edited by: Nahid Ali,

Indian Institute of Chemical Biology (CSIR), India

Reviewed by: Enrique Medina-Acosta, State University of Norte

Fluminense, Brazil

Mark Christopher Coles,

University of Oxford, United Kingdom

*Correspondence:

Alexandre B. Reis alexreis@nupeb.ufop.br, alexreisufop@gmail.com

\footnotetext{
Specialty section:

This article was submitted to Vaccines and Molecular Therapeutics, a section of the journal Frontiers in Immunology

Received: 11 January 2018 Accepted: 26 April 2018 Published: 11 May 2018
}

Citation: De Brito RCF, Cardoso JMO, Reis LES, Vieira JF, Mathias FAS, Roatt BM, Aguiar-Soares RDO,

Ruiz JC, Resende DM and Reis AB (2018) Peptide

Vaccines for Leishmaniasis.

Front. Immunol. 9:1043. doi: 10.3389/fimmu.2018.01043
${ }^{1}$ Laboratório de Pesquisas Clínicas, Programa de Pós-graduação em Ciências Farmacêuticas/CiPharma, Escola de Farmácia, Universidade Federal de Ouro Preto, Ouro Preto, Brazil, ${ }^{2}$ Laboratório de Imunopatologia, Núcleo de Pesquisas em Ciências Biológicas, Universidade Federal de Ouro Preto, Ouro Preto, Brazil, ${ }^{3}$ Instituto Nacional de Ciência e Tecnologia em Doenças Tropicais, Salvador, Brazil, ${ }^{4}$ Grupo Informática de Biossistemas e Genômica, Programa de Pós-graduação em Ciências da Saúde, Instituto René Rachou, Fundação Oswaldo Cruz, Belo Horizonte, Brazil, ${ }^{5}$ Programa de Pós-graduação em Biologia Computacional e Sistemas, Instituto Oswaldo Cruz, Fundação Oswaldo Cruz, Rio de Janeiro, Brazil

Due to an increase in the incidence of leishmaniases worldwide, the development of new strategies such as prophylactic vaccines to prevent infection and decrease the disease have become a high priority. Classic vaccines against leishmaniases were based on live or attenuated parasites or their subunits. Nevertheless, the use of whole parasite or their subunits for vaccine production has numerous disadvantages. Therefore, the use of Leishmania peptides to design more specific vaccines against leishmaniases seems promising. Moreover, peptides have several benefits in comparison with other kinds of antigens, for instance, good stability, absence of potentially damaging materials, antigen low complexity, and low-cost to scale up. By contrast, peptides are poor immunogenic alone, and they need to be delivered correctly. In this context, several approaches described in this review are useful to solve these drawbacks. Approaches, such as, peptides in combination with potent adjuvants, cellular vaccinations, adenovirus, polyepitopes, or DNA vaccines have been used to develop peptide-based vaccines. Recent advancements in peptide vaccine design, chimeric, or polypeptide vaccines and nanovaccines based on particles attached or formulated with antigenic components or peptides have been increasingly employed to drive a specific immune response. In this review, we briefly summarize the old, current, and future stands on peptide-based vaccines, describing the disadvantages and benefits associated with them. We also propose possible approaches to overcome the related weaknesses of synthetic vaccines and suggest future guidelines for their development.

\footnotetext{
Keywords: peptide-based vaccines, chimeric vaccine, polypeptide vaccines, tegumentary leishmaniases, visceral leishmaniasis
}

\section{INTRODUCTION}

The leishmaniases represent a wide spectrum of parasitic diseases caused by dimorphic protozoan of the genus Leishmania (1). The disease has an incidence ranging from 200,000 to 400,00 and from 700,000 to 1 million visceral and cutaneous leishmaniases cases, respectively, occurring each year, and a tentative estimate of 20,000-40,000 leishmaniasis deaths per year. The main clinical forms can be grouped into visceral leishmaniasis, the most severe form of the disease, which can progress to death when untreated; cutaneous leishmaniasis, the most common, which causes ulcerations on the skin; and mucocutaneous leishmaniasis, characterized as a mutilating disease that causes 
irreversible deformities, mainly of the face (2). In recent decades, Leishmania species have spread across the world and reached non-endemic areas (3).

For many decades, the traditional prophylactic strategy concerning vector control using spray insecticides, rodent control using poison baits, environmental management, and control of domestic reservoirs has been used $(4,5)$. However, none of these strategies were able to effectively decrease the number of canine and human cases (5), and a lack of commitment to preventive campaigns has been reported (6). Thus, development of new strategies for the prevention of the disease has become a high priority (7). In this context, the development of vaccines for leishmaniases becomes a promising tool for prophylaxis in endemic areas, with potential impact on the epidemiology of the disease (8). It is a consensus that Th1 immune response plays a critical role not only in protection against the primary infection but also promoting a lifelong immunity to Leishmania re-infection (9). T-cells, namely, $\mathrm{CD}^{+}$cells, are crucial in immune protection by producing various important cytokines associated with resistance, such as IFN- $\gamma$ and TNF- $\alpha$ (10). Thus, an ideal vaccine should promote a strong Th1 response against Leishmania parasites (11).

An ancient practice of immunization is leishmanization, in which live and virulent Leishmania promastigotes are injected in uninfected individuals living in endemic areas. Appearance of severe side effect suggests that leishmanization is unfit for large-scale immunization protocols (12). Regarding whole parasite vaccines, trials in dogs and humans using killed or genetically attenuated parasites. This kind of vaccines offers a huge repertoire of parasite antigens and it can promote significant protection against infection. By contrast, these vaccines display low stability and safety in comparison with other type of vaccines $(8,13-15)$. Parasite subunits-based vaccines are currently most popular in modern due to their ability to stimulate specific immune response. However, they are not completely safe and they can present side effects (16-19). Despite the existence of various studies in this area, no licensed vaccine is available for humans against any form of leishmaniases (8). Therefore, many different strategies to identify new antigens have been employed to develop a vaccine against leishmaniases (20). In this scenario, peptide-based vaccines are a very attractive alternative because they are based on a short antigenic epitope to trigger a desired immune response. This option may become a promising strategy by promoting not only protection against leishmaniases, but as a potent therapeutic tool to treat the disease (21). Minimal epitopes like peptides are able to elicited strong T-cell-specific responses that are fundamental to eliminate intracellular parasite (22).

This review aims to provide an insightful view over evolution of peptide-based vaccines in leishmaniases prophylaxis, as well as, the most recent innovations in this area.

\section{LEISHMANIAL PEPTIDE-BASED VACCINES}

Although many vaccine candidates against leishmaniases are composed of whole parasite or specific proteins, the use of only a minimal pathogen epitope which can stimulate long-lasting protection against the parasite is becoming tendency in vaccine development (22). Peptide-based vaccines are a major focus of this field because they are easier to produce and show more stability than whole attenuated pathogens (22). Furthermore, synthetic peptides have several benefits in comparison with other kinds of antigens, showing an absence of potentially damaging materials, lower antigen complexity, and low costs for scaling up (23). Regarding the immune response, peptide-based vaccines can generate specific responses and they can be combined to design multi-epitopes and/or multi-specific vaccines (24).

Peptide vaccine studies, which were becoming increasingly marginalized just a few years ago, are now on the rise as a promising approach for the rational design of vaccines (22).

In this review, we performed an extensive search for studies involving leishmanial peptide-based vaccines in PubMed and identified 30 original research studies (the methodology applied for the searching and selection the 30 articles is described in statement subtopic) which are demonstrated in Tables $\mathbf{1}$ and $\mathbf{2}$.

Although there is an increase in the number of new vaccines using peptides, a major challenge is how to avoid inactivation or degradation by the immune system and how to enhance the immunogenicity of those peptides. Thus, it is necessary to design vaccines using different approaches and to use other compounds such as adjuvants that can help to enhance the antigen immunogenicity (54).

\section{Strategies for Peptide Mapping}

Epitope choice is a crucial stage to develop a peptide vaccine. Consequently, at first, suitable epitopes on the protein or whole proteome of interest need to be mapped. These epitopes must be able to induce strong, long-lasting cellular immunity against Leishmania parasites. Peptide epitopes can be identified using various approaches and methodologies (Figure 1). Regarding viscerotropic and dermatotropic species of Leishmania, potential immunogenic peptides can be mapped from the whole parasite proteome, proteins that previous elicited immunological outcome, and/or using known peptide libraries. In this scenario, two different analyses can be performed as shown in Figure 1.

The first is the in silico approach that is usually focused on prediction of T- and B-cell epitopes, phylogenetic analysis for the identification of conserved leishmanial epitopes Leishmania species, or prediction of protein/peptide localization in the parasite. Many algorithms are used to predict affinity binding of peptide epitopes on MHC class I and II molecules, linear or discontinuous B-cell peptide epitopes, or even signal peptides that direct proteins to different subcellular localizations, as shown on Tables 1 and 2. Until recently, vaccine development was associated with conventional methods such as biochemical, immunological, and microbiological approaches using the whole, or part of, the pathogens. With the advent of post-genomic techniques and immunoinformatics for immune system data analysis, reverse vaccinology is becoming a useful tool to design and develop vaccines. Basically, reverse vaccinology uses immunoinformatics for epitope mapping across an entire pathogen genome using predictive algorithms that are 
TABLE 1 | Summary of peptides evaluated as potential vaccine candidates against visceral leishmaniasis.

\begin{tabular}{|c|c|c|c|c|c|c|c|c|c|c|}
\hline \multirow[t]{2}{*}{ Protein } & \multirow[t]{2}{*}{ Species } & \multirow{2}{*}{$\begin{array}{l}\text { Epitope } \\
\text { (residue) }\end{array}$} & \multirow[t]{2}{*}{ Finding method } & \multirow{2}{*}{$\begin{array}{l}\text { Host } \\
\text { organism }\end{array}$} & \multirow[t]{2}{*}{ Dose/route } & \multirow[t]{2}{*}{ Adjuvant } & \multirow[t]{2}{*}{ Challenge } & \multicolumn{2}{|c|}{ Main remarks } & \multirow[t]{2}{*}{ Reference } \\
\hline & & & & & & & & Immune response & $\begin{array}{l}\text { Parasite load } \\
\text { or lesion size }\end{array}$ & \\
\hline \multirow[t]{2}{*}{ GP63 } & $\begin{array}{l}\text { Leishmania } \\
\text { donovani }\end{array}$ & Polytope (561bp) & In vitro assay & $\begin{array}{l}\text { BALB/c } \\
\text { mice }\end{array}$ & $100 \mu \mathrm{g} / \mathrm{IM}$ & - & $\begin{array}{l}2 \times 10^{7} \\
\text { L. donovani } \\
\text { promastigotes }\end{array}$ & $\uparrow \mathrm{IFN}-\gamma$ and IL-2, $\downarrow \| \mathrm{L}-10$ & $\begin{array}{l}\downarrow \text { Parasite load in } \\
\text { spleen and liver }\end{array}$ & (25) \\
\hline & L. donovani & $\begin{array}{l}\text { P1-4 peptides } \\
\text { (15-21 aa) }\end{array}$ & In silico prediction (EpiMatrix) & $\begin{array}{l}\text { Human } \\
\text { PBMC }\end{array}$ & $100 \mu g$ & - & - & $\begin{array}{l}\mathrm{P} 1: \uparrow \mathrm{IL}-10 \text { in PBMCs } \\
\mathrm{P} 4: \downarrow \mathrm{L}-10 \text { in PBMCs }\end{array}$ & - & (26) \\
\hline \multirow[t]{3}{*}{ KMP-11 } & L. donovani & 84 peptides (8 aa) & In vitro epitope binding assay & $\begin{array}{l}\text { Human } \\
\text { PBMC }\end{array}$ & $\begin{array}{l}44 \mu \mathrm{g} \mathrm{mL}^{-1} \text { to } \\
\text { pulse APC }\end{array}$ & - & - & $\uparrow \mathrm{IFN}-\gamma$ by $\mathrm{CD} 8^{+}$ & - & (27) \\
\hline & $\begin{array}{l}\text { Leishmania } \\
\text { infantum }\end{array}$ & $\begin{array}{l}\text { P12-31 peptide } \\
\text { (12-31 aa) }\end{array}$ & $\begin{array}{l}\text { In silico prediction (NetMHC3.0 } \\
\text { and NetMHCll1.0) }\end{array}$ & $\begin{array}{l}\text { BALB/c } \\
\text { mice }\end{array}$ & $\begin{array}{l}10 \mu \mathrm{gL}^{-1 /} \\
\mathrm{BM}-\mathrm{DCs} / \mathrm{IV}\end{array}$ & CpG ODN & $\begin{array}{l}1 \times 10^{7} \\
\text { L. infantum } \\
\text { promastigotes }\end{array}$ & $\begin{array}{l}\uparrow \mathrm{IFN}-\gamma, \mathrm{IL}-10 \text {, and IL-17; } \uparrow \\
\text { spleen cells proliferation }\end{array}$ & $\begin{array}{l}\downarrow \text { Parasite load in } \\
\text { spleen and liver }\end{array}$ & (28) \\
\hline & L. infantum & P1 (20 aa) & $\begin{array}{l}\text { In silico prediction (SYFPEITHI, } \\
\text { BIMAS, and NetMHCII1.0) }\end{array}$ & $\begin{array}{l}\text { BALB/c } \\
\text { mice }\end{array}$ & $50 \mu \mathrm{g} / \mathrm{SC}$ & $\begin{array}{l}\text { CFA and } \\
\text { IFA }\end{array}$ & - & $\begin{array}{l}\text { Poorly immunogenic; no } \\
\text { proliferative effects and cytokine } \\
\text { secretion }\end{array}$ & - & (29) \\
\hline A2 & L. donovani & $\begin{array}{l}\text { Four peptides } \\
\text { (17-21 aa) peptides }\end{array}$ & $\begin{array}{l}\text { In silico prediction (BIMAS } \\
\text { and Protscale) }\end{array}$ & $\begin{array}{l}\text { BALB/c } \\
\text { mice }\end{array}$ & $\begin{array}{l}5 \mu \mathrm{M} / \text { pulsed } \\
\text { splenocytes/IV }\end{array}$ & - & $\begin{array}{l}1 \times 10^{7} \\
\text { L. infantum } \\
\text { promastigotes }\end{array}$ & $\begin{array}{l}\text { CD4- } 2 \text { and CD8 peptides: } \\
\uparrow \text { IFN- } \gamma \text { by T-cells } \\
\text { CD8 peptide: } \uparrow \text { specific } \\
\text { cytotoxicity by CD8 }{ }^{+} \text {T-cells }\end{array}$ & - & (30) \\
\hline NH36 & L. donovani & $\begin{array}{l}\mathrm{F} 1, \mathrm{~F} 2 \text {, and F3 } \\
\text { peptides ( 100 aa) }\end{array}$ & $\begin{array}{l}\text { Fragmentation of } \mathrm{NH} 36 \\
\text { in } 3 \text { antigens }\end{array}$ & $\begin{array}{l}\text { BALB/c } \\
\text { mice }\end{array}$ & $100 \mu \mathrm{g} / \mathrm{SC}$ & Saponin & $\begin{array}{l}3 \times 10^{7} \\
\text { L. infantum } \\
\text { amastigotes }\end{array}$ & $\begin{array}{l}\uparrow \mathrm{IFN}-\gamma / \mathrm{LL}-10 \text { and TNF- } \alpha / \mathrm{IL}-10 \\
\text { ratio by } \mathrm{CD} 4^{+} \text {and } \mathrm{CD} 8^{+} \text {T-cells }\end{array}$ & $\begin{array}{l}\text { F3: } \downarrow \text { parasite } \\
\text { load in liver }\end{array}$ & (31) \\
\hline $\begin{array}{l}\text { Phage display } \\
\text { library }\end{array}$ & L. infantum & $\begin{array}{l}20 \text { phages with } \\
\text { peptides ( } 7 \mathrm{aa})\end{array}$ & $\begin{array}{l}\text { In vitro selection } \\
\text { (Bio-panning cycles) }\end{array}$ & $\begin{array}{l}\text { BALB/c } \\
\text { mice }\end{array}$ & $\begin{array}{l}1 \times 10^{11} \\
\text { phages/SC }\end{array}$ & Saponin & $\begin{array}{l}1 \times 10^{7} \\
\text { L. infantum } \\
\text { promastigotes }\end{array}$ & $\begin{array}{l}\text { B10 or C01: } \uparrow \text { IFN- } \gamma \text {, IL-12, } \\
\text { and GM-CSF; } \downarrow \text { IL-10 and IL-4 }\end{array}$ & $\begin{array}{l}\text { B10 or C01: } \downarrow \\
\text { parasite load in } \\
\text { liver, spleen, dLN, } \\
\text { and BM }\end{array}$ & (32) \\
\hline $\begin{array}{l}\text { KMP-11, CPA, } \\
\text { CPB, TSA, and } \\
\text { P74 }\end{array}$ & $\begin{array}{l}\text { Leishmania } \\
\text { spp. }\end{array}$ & 397 peptides (10 aa) & $\begin{array}{l}\text { In silico analysis } \\
\text { (conservation analyses) }\end{array}$ & $\begin{array}{l}\text { BALB/cj } \\
\text { mice }\end{array}$ & $\begin{array}{l}0.2,2,10 \\
\text { and } 20 \mu \mathrm{g}\end{array}$ & - & $\begin{array}{l}10 \times 10^{6} \\
\text { L. donovani } \\
\text { promastigotes }\end{array}$ & $\begin{array}{l}\text { DNA vaccine: } \uparrow \mathrm{IFN}-\gamma \\
\text { and TNF- } \alpha\end{array}$ & $\begin{array}{l}\text { DNA vaccine: } \downarrow \\
\text { parasite load in } \\
\text { spleen and liver }\end{array}$ & (24) \\
\hline $\begin{array}{l}\text { Hypothetical } \\
\text { protein }\end{array}$ & L. infantum & $\begin{array}{l}\text { Two peptides } \\
\text { (9 and } 17 \text { aa) }\end{array}$ & In silico prediction (BIMAS) & $\begin{array}{l}\text { BALB/c } \\
\text { mice }\end{array}$ & $25 \mu \mathrm{g} / \mathrm{SC}$ & Saponin & $\begin{array}{l}1 \times 10^{7} \\
\text { L. infantum } \\
\text { promastigotes }\end{array}$ & $\downarrow \mid \mathrm{IL}-4$ and IL-10 & $\begin{array}{l}\text { P2: } \downarrow \text { parasite } \\
\text { load in the spleen }\end{array}$ & (33) \\
\hline 3'-Nucleotidase & L. donovani & 5 peptides (9 aa) & $\begin{array}{l}\text { In silico prediction (SYFPEITHI, } \\
\text { BIMAS, RANKpepProPredl, } \\
\text { and NetMHCpan) }\end{array}$ & $\begin{array}{l}\text { Human } \\
\text { PBMC }\end{array}$ & $10 \mu \mathrm{mL}^{-1}$ & - & - & $\begin{array}{l}\uparrow \text { IFN- } \gamma \text { and IL-2; } \uparrow \text { T-cell } \\
\text { proliferation in PBMC culture } \\
\text { and CTL activity }\end{array}$ & - & (34) \\
\hline
\end{tabular}

GP63, glycoprotein 63; KMP-11, kinetoplastid membrane protein-11; A2, amastigote virulent factor; NH36, nucleoside hydrolase 36; CPA, cysteine peptidase A; CPB, cysteine proteinase B; TSA, thiol-specific antioxidant; P74,

elongation factor 1-alpha; IFA, incomplete Freund's adjuvant; CFA, complete Freund's adjuvant; PBMC, peripheral blood mononuclear cell; CpG ODN, CpG oligodeoxynucleotides. 
TABLE 2 | Summary of peptides evaluated as potential vaccine candidates against cutaneous leishmaniasis

\begin{tabular}{|c|c|c|c|c|c|c|c|c|c|c|}
\hline \multirow[t]{2}{*}{ Protein } & \multirow[t]{2}{*}{ Species } & \multirow{2}{*}{$\begin{array}{l}\text { Epitope } \\
\text { (residue) }\end{array}$} & \multirow[t]{2}{*}{ Finding method } & \multirow{2}{*}{$\begin{array}{l}\text { Host } \\
\text { organism }\end{array}$} & \multirow[t]{2}{*}{ Dose/route } & \multirow[t]{2}{*}{ Adjuvant } & \multirow[t]{2}{*}{ Challenge } & \multicolumn{2}{|c|}{ Main remarks } & \multirow[t]{2}{*}{ Reference } \\
\hline & & & & & & & & Immune response & $\begin{array}{l}\text { Parasite load } \\
\text { or lesion size }\end{array}$ & \\
\hline \multirow[t]{7}{*}{ GP63 } & $\begin{array}{l}\text { Leishmania } \\
\text { major }\end{array}$ & $\begin{array}{l}24 \text { peptides } \\
\text { (12-35 aa) }\end{array}$ & $\begin{array}{l}\text { In silico prediction } \\
\text { (AMPHI) }\end{array}$ & $\begin{array}{l}\text { CBA and } \\
\text { BALB/C mice }\end{array}$ & $100 \mu \mathrm{g} / \mathrm{SC}$ or IV & $\begin{array}{l}\text { Corynebacterium } \\
\text { parvum }\end{array}$ & $\begin{array}{l}1 \times 10^{7} \mathrm{~L} \text {. major } \\
\text { promastigotes }\end{array}$ & $\begin{array}{l}\uparrow I \mathrm{~L}-2 \text { and IFN- } \gamma \\
\uparrow \mathrm{DTH} \text { response }\end{array}$ & $\begin{array}{l}\text { P146-171 peptide: } \\
\downarrow \text { lesion size }\end{array}$ & (35) \\
\hline & L. major & $\begin{array}{l}7 \text { peptides } \\
\text { (14 aa) }\end{array}$ & In silico prediction & BALB/c mice & $100 \mu \mathrm{g} / \mathrm{SC}$ & $8 \%$ poloxamer 407 & $\begin{array}{l}2 \times 10^{4} \mathrm{~L} \text {. major } \\
\text { promastigotes }\end{array}$ & $\begin{array}{l}\uparrow \mathrm{CD} 4+\text { subset } \\
\text { proliferation }\end{array}$ & PT3: $\downarrow$ lesion size & (36) \\
\hline & L. major & $\begin{array}{l}13 \text { peptides } \\
\text { (14 aa) }\end{array}$ & In silico prediction & Human PBMC & $50 \mu \mathrm{gL}^{-1}$ & - & - & $\begin{array}{l}\text { PT4, PT7, and PT8: } \\
\uparrow \text { PBMC proliferation; } \\
\uparrow \mathrm{IFN}-\gamma\end{array}$ & - & (37) \\
\hline & L. major & $\begin{array}{l}\text { P154 and } \\
\text { P467 modified } \\
\text { peptides (16 aa) }\end{array}$ & $\begin{array}{l}\text { In silico prediction } \\
\text { (AMPHI) }\end{array}$ & CBA mice & $50 \mu \mathrm{g} / \mathrm{SC}$ or IP & - & $\begin{array}{l}1 \times 10^{4} \mathrm{~L} \text {. major } \\
\text { promastigotes }\end{array}$ & $\begin{array}{l}\uparrow \text { IFN- } \gamma \text { and IL-2; } \\
\uparrow \mathrm{GM}-\mathrm{CSF}\end{array}$ & $\begin{array}{l}\text { P467 by SC: } \\
\downarrow \text { lesion size }\end{array}$ & (38) \\
\hline & L. major & $\begin{array}{l}\text { PT3 peptide } \\
\text { (16 aa) }\end{array}$ & In silico prediction & BALB/c mice & $100 \mu \mathrm{g} / \mathrm{SC}$ & $8 \%$ poloxamer 407 & $\begin{array}{l}2 \times 10^{4} \mathrm{~L} \text {. major } \\
\text { promastigotes }\end{array}$ & - & $\downarrow$ Lesion size & (39) \\
\hline & L. major & $\begin{array}{l}\mathrm{L} 1 \text { and } \mathrm{L} 2 \\
\text { peptides (16 aa) }\end{array}$ & In silico prediction & BALB/c mice & $\begin{array}{l}100 \mu \mathrm{g} \mathrm{mL} \mathrm{L}^{-1 /} \\
\text { BM-DCs/IV }\end{array}$ & - & $\begin{array}{l}5 \times 10^{5} \mathrm{~L} . \text { major } \\
\text { promastigotes }\end{array}$ & $\begin{array}{l}\mathrm{L} 1: \uparrow \mathrm{IFN}-\gamma \\
\text { and IL-4 }\end{array}$ & $\begin{array}{l}\downarrow \text { Footpad swelling; } \\
\downarrow \text { parasite load in } L N\end{array}$ & (40) \\
\hline & $\begin{array}{l}\text { Leishmania } \\
\text { mexicana/L. } \\
\text { major }\end{array}$ & $\begin{array}{l}\text { HLA-A2 } \\
\text { peptides (9 aa) }\end{array}$ & $\begin{array}{l}\text { In silico prediction } \\
\text { (SYFPEITHI) }\end{array}$ & $\begin{array}{l}\mathrm{BALB} / \mathrm{c} \text { and } \\
\mathrm{HHDIl} \text { transgenic } \\
\text { mice }\end{array}$ & $\begin{array}{l}100+140 \mu g \text { of } \\
\text { helper peptide/IV }\end{array}$ & IFA & $\begin{array}{l}2 \times 10^{6} \\
\text { L. mexicana } \\
\text { promastigotes }\end{array}$ & $\begin{array}{l}\text { C2 peptide: } \uparrow \text { CTL } \\
\text { activity and } \uparrow \text { IFN- } \gamma \text { in } \\
\text { HHDII mice; } \uparrow C T L \\
\text { activity in BALB/c mice }\end{array}$ & - & (41) \\
\hline KMP-11 & $\begin{array}{l}\text { Leishmania } \\
\text { panamensis }\end{array}$ & $\begin{array}{l}6 \text { overlapping } \\
\text { peptides (20 aa) }\end{array}$ & $\begin{array}{l}\text { In vitro epitope } \\
\text { binding assay }\end{array}$ & Human PBMC & $\begin{array}{l}10 \mu \mathrm{g} \mathrm{mL}^{-1} \text { to } \\
\text { pulse APCs }\end{array}$ & - & - & $\begin{array}{l}\uparrow \text { Lymphoproliferation; } \\
\uparrow \text { IFN- } \gamma \text { by T-cells }\end{array}$ & - & (42) \\
\hline $\begin{array}{l}\text { Whole } \\
\text { proteome }\end{array}$ & L. major & $\begin{array}{l}26 \text { peptides } \\
\text { (9-10 aa) }\end{array}$ & $\begin{array}{l}\text { In silico prediction } \\
\text { (SYFPEITHI, BIMAS, } \\
\text { ProPred-I, and MAPPP) }\end{array}$ & BALB/c mice & $\begin{array}{l}250 \mu \mathrm{g} \text { per } \\
\mathrm{pool} / \mathrm{SC}\end{array}$ & CFA & - & $\begin{array}{l}14 \text { of } 26 \text { peptides: } \\
\uparrow \text { IFN- } \gamma \text { by CD } 4^{+} \\
\text {and CD8 } 8^{+} \text {-cells }\end{array}$ & - & (43) \\
\hline CPB & $\begin{array}{l}\text { Leishmania } \\
\text { amazonensis }\end{array}$ & $\begin{array}{l}9 \text { peptides } \\
\text { (8-10 aa) }\end{array}$ & $\begin{array}{l}\text { In silico prediction } \\
\text { (SYFPEITHI, NetChop, } \\
\text { and PAProC) }\end{array}$ & $\begin{array}{l}\text { BALB/c and } \\
\text { CBA mice }\end{array}$ & $30 \mu \mathrm{gL}^{-1}$ & - & $\begin{array}{l}1 \times 10^{6} \\
\text { L. amazonensis } \\
\text { promastigotes }\end{array}$ & $\begin{array}{l}\uparrow \mathrm{IFN}-\gamma, \mathrm{IL}-12, \mathrm{IL}-4 \text {, } \\
\text { and IL-10; blastogenesis } \\
\text { in } \mathrm{LN} \text { cells }\end{array}$ & - & (44) \\
\hline LACK & L. major & $\begin{array}{l}\text { P158-173 } \\
\text { peptide (16 aa) }\end{array}$ & $\begin{array}{l}\text { Immunodominance } \\
\text { by in vitro assay }\end{array}$ & BALB/c mice & $1.5 \times 10^{7} \mathrm{pfu} / \mathrm{IP}$ & - & $\begin{array}{l}1 \times 10^{\circ} \mathrm{L} \text {. major } \\
\text { promastigotes }\end{array}$ & $\begin{array}{l}\uparrow \text { IFN- } \gamma \text { by } \\
\mathrm{CD} 4^{+} \text {T-cells } \\
\text { in spleen }\end{array}$ & $\begin{array}{l}\downarrow \text { Lesion size; } \\
\downarrow \text { parasite load } \\
\text { in dLN }\end{array}$ & (45) \\
\hline CPB & L. amazonensis & $\begin{array}{l}7 \mathrm{H} 2 \text { peptides } \\
(8-10 \text { aa) }\end{array}$ & $\begin{array}{l}\text { In silico prediction } \\
\text { (SYFPEITHI) }\end{array}$ & $\begin{array}{l}\mathrm{BALB} / \mathrm{c} \text { and } \\
\mathrm{C} 57 \mathrm{BL} / 6 \text { mice }\end{array}$ & $30 \mu \mathrm{g} \mathrm{mL}^{-1}$ & - & $\begin{array}{l}\text { L. amazonensis } \\
\text { promastigotes }\end{array}$ & $\begin{array}{l}\uparrow \mathrm{CD}^{+} \mathrm{T} \text {-cells } \\
\text { proliferation }\end{array}$ & - & (46) \\
\hline $\begin{array}{l}\text { CPB, CPC, } \\
\text { TSA, LelF, } \\
\text { LmSTI, and LPG }\end{array}$ & L. major & $\begin{array}{l}18 \text { peptides } \\
(9 \text { aa) }\end{array}$ & $\begin{array}{l}\text { in silico prediction } \\
\text { (SYFPEITHI, BIMAS, } \\
\text { EpiJen, RANKpep, } \\
\text { Multipred, NetCTL, } \\
\text { and nHLApred) }\end{array}$ & Human PBMC & $10 \mu \mathrm{gL}^{-1}$ & - & - & $\begin{array}{l}\text { Peptide pools: } \\
\uparrow \text { IFN- } \gamma \text { by } \\
\text { CD8+ T-cells }\end{array}$ & - & (47) \\
\hline $\begin{array}{l}\text { CPB, CPC, } \\
\text { LmSTI, LPG, and } \\
\text { other antigens }\end{array}$ & L. major & $\begin{array}{l}\text { Polytope } \\
\text { (561 bp) }\end{array}$ & $\begin{array}{l}\text { In silico prediction } \\
\text { (BIMAS) }\end{array}$ & BALB/c mice & $50 \mu \mathrm{g} / \mathrm{SC}$ & - & $\begin{array}{l}2 \times 10^{5} \mathrm{~L} \text {. major } \\
\text { promastigotes }\end{array}$ & $\begin{array}{l}\uparrow \text { IFN- } \gamma \text { by } \\
\text { spleen cells }\end{array}$ & $\begin{array}{l}\downarrow \text { Parasite load in } \\
\text { dLN; } \downarrow \text { footpad } \\
\text { swelling }\end{array}$ & (48) \\
\hline
\end{tabular}


TABLE 2 | Continued

\begin{tabular}{|c|c|c|c|c|c|c|c|c|c|c|}
\hline \multirow[t]{2}{*}{ Protein } & \multirow[t]{2}{*}{ Species } & \multirow{2}{*}{$\begin{array}{l}\text { Epitope } \\
\text { (residue) }\end{array}$} & \multirow[t]{2}{*}{ Finding method } & \multirow{2}{*}{$\begin{array}{l}\text { Host } \\
\text { organism }\end{array}$} & \multirow[t]{2}{*}{ Dose/route } & \multirow[t]{2}{*}{ Adjuvant } & \multirow[t]{2}{*}{ Challenge } & \multicolumn{2}{|c|}{ Main remarks } & \multirow[t]{2}{*}{ Reference } \\
\hline & & & & & & & & Immune response & $\begin{array}{l}\text { Parasite load } \\
\text { or lesion size }\end{array}$ & \\
\hline $\begin{array}{l}\text { Phage display } \\
\text { library }\end{array}$ & $\begin{array}{l}\text { Leishmania } \\
\text { infantum }\end{array}$ & $\begin{array}{l}\text { Two phages } \\
\text { containing } \\
\text { peptides ( } 7 \text { aa) }\end{array}$ & $\begin{array}{l}\text { In vitro selection } \\
\text { (bio-panning cycles) }\end{array}$ & BALB/c mice & $\begin{array}{l}5 \times 10^{10} \\
\text { phages/SC }\end{array}$ & Saponin & $\begin{array}{l}1 \times 10^{6} \\
\text { L. amazonensis } \\
\text { promastigotes }\end{array}$ & $\begin{array}{l}\uparrow \mathrm{IFN}-\gamma, \mathrm{IL}-12 \text {, } \\
\text { and GM-CSF }\end{array}$ & $\begin{array}{l}\downarrow \text { Parasite load in } \\
\text { liver, spleen, dLN, } \\
\text { and BM; } \downarrow \text { lesion } \\
\text { size in footpad }\end{array}$ & (49) \\
\hline $\begin{array}{l}\text { CPA, CPB, } \\
\text { GP63, H3 and } \\
\text { H4 histone } \\
\text { LPG-2 }\end{array}$ & $\begin{array}{l}\text { Leishmania } \\
\text { braziliensis }\end{array}$ & $\begin{array}{l}8 \text { peptides } \\
\text { ( } 9 \text { aa) }\end{array}$ & $\begin{array}{l}\text { In silico prediction } \\
\text { (EPIBOT platform) }\end{array}$ & BALB/c mice & $\begin{array}{l}\text { Peptide-pulsed } \\
\text { splenocytes/IV }\end{array}$ & - & $\begin{array}{l}1 \times 10^{5} \\
\text { L. braziliensis } \\
\text { promastigotes }\end{array}$ & $\begin{array}{l}\text { Three peptides: } \\
\uparrow \text { in vivo cytotoxicity } \\
\text { by specific splenocytes } 1\end{array}$ & - & (50) \\
\hline $\begin{array}{l}33 \text { different } \\
\text { proteins }\end{array}$ & L. major & $\begin{array}{l}78 \text { peptides } \\
\text { ( } 9 \text { aa) }\end{array}$ & $\begin{array}{l}\text { In silico prediction } \\
\text { (SYFPEITHI, } \\
\text { BIMAS, RANKpep, } \\
\text { and NetMHC) }\end{array}$ & Human PBMC & $\begin{array}{l}20 \mu \mathrm{g} \text { (each) or } \\
1 \mu \mathrm{g} \text { per pool }\end{array}$ & - & - & $\begin{array}{l}\text { Six peptides: } \\
\uparrow \text { granzyme B }\end{array}$ & - & (51) \\
\hline $\begin{array}{l}\text { Phage display } \\
\text { library }\end{array}$ & L. major & $\begin{array}{l}6 \text { peptides } \\
\text { ( } 6 \text { aa) }\end{array}$ & $\begin{array}{l}\text { In vitro selection } \\
\text { (bio-panning) }\end{array}$ & $\begin{array}{l}\text { Human } \\
\text { PBMC and } \\
\text { BALB/c mice }\end{array}$ & $100 \mu \mathrm{M} / \mathrm{SC}$ & - & $\begin{array}{l}1 \times 10^{\circ} \mathrm{L} \text {. major } \\
\text { metacyclic } \\
\text { promastigotes }\end{array}$ & - & $\begin{array}{l}\text { P1 and P2 peptides } \\
\text { inhibited human } \\
\text { monocyte infection. } \\
\text { P2: } \downarrow \text { footpad } \\
\text { swelling and } \\
\downarrow \text { parasite load in } \\
\text { footpad, LN, } \\
\text { and spleen }\end{array}$ & (52) \\
\hline $\begin{array}{l}\text { Whole } \\
\text { proteome }\end{array}$ & $\begin{array}{l}\text { L. braziliensis, } \\
\text { L. major, and } \\
\text { L. infantum }\end{array}$ & $\begin{array}{l}10 \text { peptides } \\
\text { (15 aa) }\end{array}$ & $\begin{array}{l}\text { Reverse vaccinology } \\
\text { approach }\end{array}$ & Human PBMC & $20 \mu \mathrm{gL}^{-1}$ & - & - & $\begin{array}{l}5 \text { peptides: } \\
\uparrow \text { PBMC } \\
\text { proliferation }\end{array}$ & - & (53) \\
\hline
\end{tabular}

DTH, delay-type hypersensitivity; GP63, glycoprotein 63; KMP-11, kinetoplastid membrane protein-11; CPB, cysteine proteinase B; LACK, Leishmania homolog of receptors for activated C kinase; CPC, cysteine peptidase C; TSA, thiol-specific antioxidant; LelF, elongation initiation factor-2 alpha subunit; LmSTI, L. major stress-inducible protein 1; LPG, lipophosphoglycan biosynthetic protein; H3 and H4, histones proteins 3 and 4; PBMC, peripheral blood mononuclear cell; APC, antigen-presenting cell; DC, dendritic cell: CPA, cysteine peptidase A: CFA, complete Freund's adjuvant; IFA, incomplete Freund's adjuvant. 


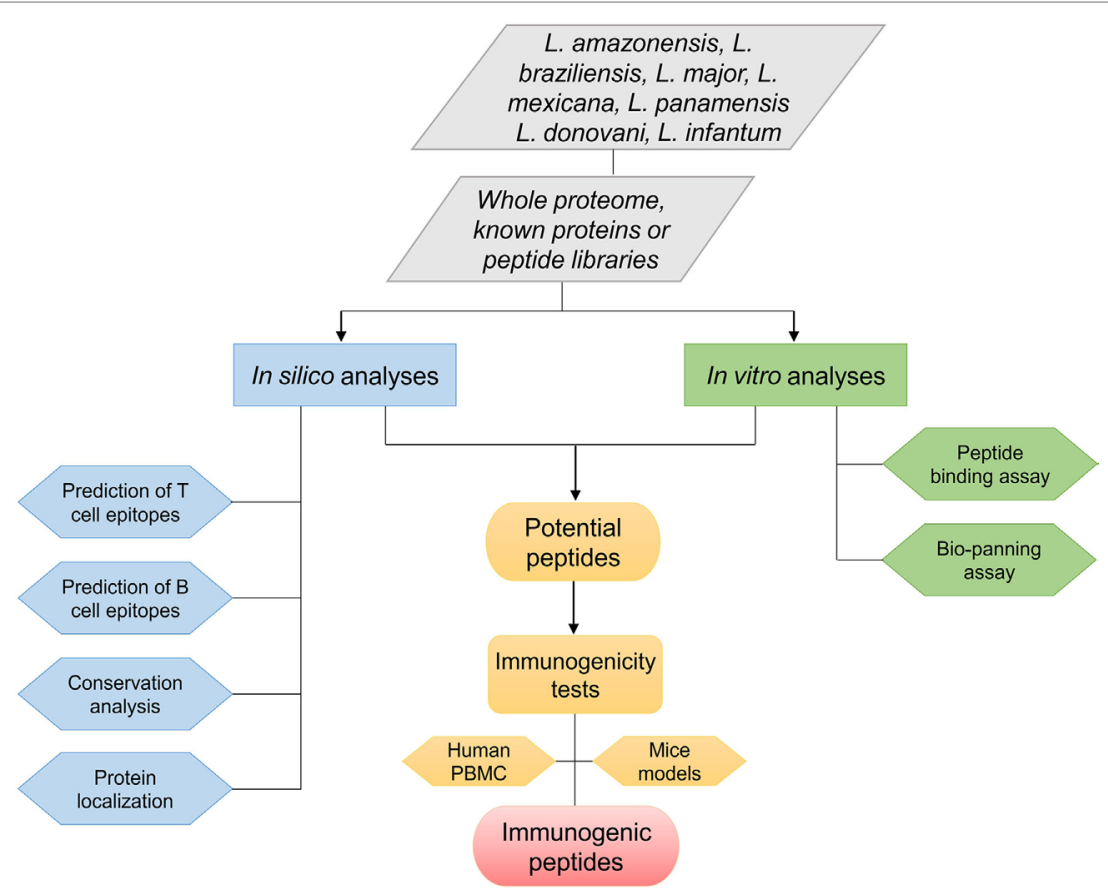

FIGURE 1 | Flowchart of various approaches used to identify promising immunogenic peptides of different Leishmania species.

able to predict $\mathrm{T}$ - and $\mathrm{B}$-cells peptide epitopes. There are many advantages with this strategy, the most important being the decrease of time and cost needed to identify potential vaccine candidates $(55,56)$. Immunoinformatics started to be applied for leishmaniases research in the early 1990s with T-cell predictive algorithms such as AMPHI method (now it is obsolete) in known immunogenic proteins (35). Various studies have since been performed using peptide epitope predictions in previously known immunogenic proteins. These algorithms have become more powerful in predicting epitopes, and they can be combined to increase the accuracy for large-scale peptide epitope predictions in Leishmania proteomes $(57,58)$. Thus, today it is possible to perform high-throughput screening in whole Leishmania proteomes and identify peptides that elicit protective immune responses in vitro as well as in vivo $(43,53)$.

The second analysis is in vitro toward the discovery of new epitopes to be evaluated in biotechnological applications. Thus, phage display technology is focused on DNA recombination technology, resulting in the expression of a peptide, which mimics the structure of an epitope (termed mimotopes), on the surface of phage clones (59). This approach comprises in vitro selection process, binding affinity assays using mimotopes (biopanning) that mimic peptides exposed on the phage surface with subsequent analysis of these peptides by DNA sequencing based on binding affinity. Phage display has been employed successfully in wide variety of applications, such as vaccine development, drug discovery, diagnosis and therapeutic studies (60). For example, in a study evaluating peptides from Leishmania infantum selected throw phage display, the authors observed that two potential peptides (B10-LSFPFPG and C01-FTSFSPY) were able to induce IFN- $\gamma$, IL-12, and GM-CSF production in mice splenocytes after challenge. These peptides were able to reduce the parasite load in liver, spleen, lymph nodes, and bone marrow and to reduce lesion size in footpad after L. infantum challenge (49). Rhaiem and Houimel (52) showed the potential of these approaches to identify immunogenic peptides. The authors demonstrated that P1 (MSKPKQ) and P2 (MAAKYN) peptides identified by phage display inhibited human monocyte infection by Leishmania major, with $\mathrm{P} 2$ promoting a reduction in footpad swelling and parasite load in footpad, lymph nodes, and spleen after challenge.

Immunodominance assays and peptide competition assays are used to identify and characterize T-cell epitopes based on antigen-presenting cells (APCs) or fluorescence-labeled peptides (27). In this field, the ability of APCs to present epitopes is assessed using T-cell hybridoma as responder cells. Immunodominant peptides are selected based on their sensitivity and recognition by stablished T-cell lines or hybridoma (61). Finally, it is possible to identify peptide expression of MHC molecules on the surface of APCs, by protein sequencing or immunochemistry. With this approach it is possible to identify leishmanial antigen epitopes for T-cells. For example, Basu et al. (27) identified for the first time a specific T-cell epitopes derived from kinetoplastid membrane protein-11 (KMP-11) protein, and they demonstrated that the use of in vitro approaches allows the identification of naturally processed epitopes. In this study mentioned earlier, the authors showed that peptides derived from Leishmania donovani promoted a significant IFN- $\gamma$ production by human CD8 ${ }^{+}$T-cells.

In brief, in silico and in vitro approaches to map potential peptides seem to be attractive tools for the development of peptide vaccine. The potential peptides identified usually are tested for 
their immunogenicity capacities using mice models $(25,28-30)$ or human peripheral blood mononuclear cells (PBMCs) from healthy/non-healthy patients $(26,34,53)$ for future peptide vaccine development, as in the studies described in Tables $\mathbf{1}$ and $\mathbf{2}$.

\section{Approaches for Peptide Vaccine Design}

Several approaches for peptide-based vaccines design were created to overcome the weak peptide immunogenicity of the peptides and poor delivery (22). In Figure 2, the most widely used approaches to develop peptide-based vaccines are shown. After identification of a potential immunogenic peptide, it can be synthetized and used with a specific adjuvant to solve the issue with low immunogenicity. Nowadays, there is an extensive variety of adjuvants that show efficacy in the induction of immune responses against peptides (54). They are usually agonists of toll-like receptors or proteins on the surface of APCs which recognize pathogen-associated molecular pattern molecules (54). The choice of an adjuvant (or another strategy for peptide vaccine design) is the second major challenge in peptide vaccine development (54). For example, Agallou et al. (29) formulated peptide-based vaccines using an oil-water emulsion, like incomplete Freund's adjuvant or complete Freund's adjuvant. The authors demonstrated that peptides selected through in silico approaches and associated with Freund's adjuvants enhanced the immunogenicity of these vaccines; however, peptides derived from the KMP-11 did not display significant immunogenicity. Other adjuvants, for example, surfactants such as poloxamer $(8 \%)(36,39)$, or Quillaja saponaria bark saponin
(31-33) and Corynebacterium parvum (35) have been used to compose peptide-based vaccines in the last decades as shown in Tables 1 and 2. Unmethylated CpG oligodeoxynucleotides are also potent agonists for dendritic cells (DCs) activation and maturation, inducing the expression of $\mathrm{MHC}$ and costimulatory molecules that play a central role directing Th1 response crucial to Leishmania resistance (28).

Another weakness of peptide-based vaccines is the delivery of synthetic peptides. In this context, many approaches must be taken to protect protease-sensitive epitopes from degradation in vivo (22). Cellular vaccination, one of these approaches, comprises the in vitro stimulation of DCs and subsequent immunization of mice (or another organism). For example, this type of vaccination has shown efficacy in mice challenged with L. infantum parasites. Agallou and colleagues, using cellular vaccination, were able to promote a significant IFN- $\gamma$ and IL-17 production and proliferation of splenocytes. Moreover, a reduction in parasite load in the liver and spleen of challenged mice was observed (28). More recently, with the advance of recombinant DNA technology, DNA sequences for peptides have been used to design DNA vaccines $(25,48)$ or to develop attenuated virus (e.g., adenovirus) or phage display that can translate the peptide sequence and drive strong T-cell responses $(32,45,49)$. DNA and adenovirus vaccines (Figure 2) have demonstrated to be strong inducers of T-cell activation leading to intracellular parasite control $(24,30)$. Several studies emphasize that these approaches are the future for peptide vaccine design (24, 25, 30, 48). For example, Das et al. (24) proposed a polyepitope

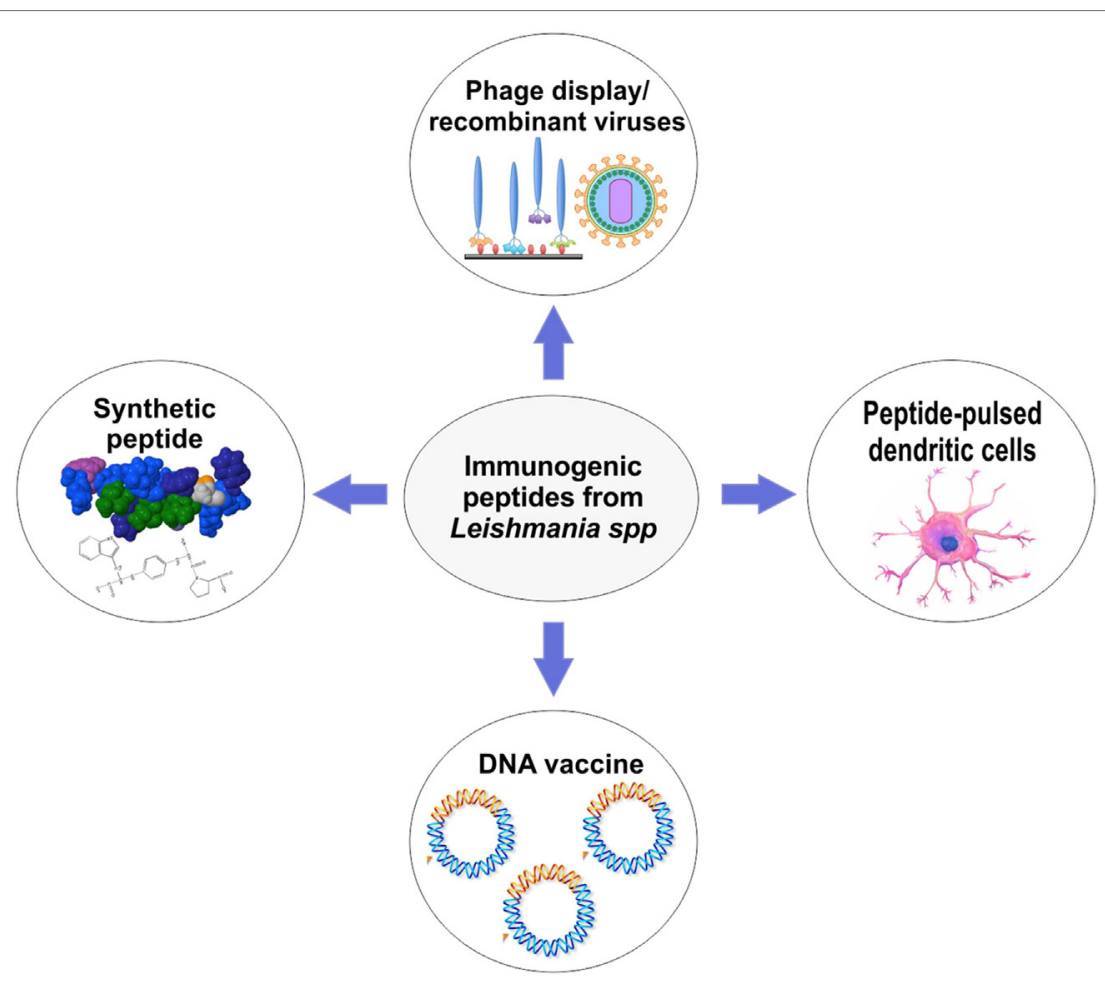

FIGURE 2 | Overview of approaches that can be used for peptide-based vaccines development against cutaneous and visceral leishmaniasis. 
DNA vaccine that showed promising results in mice. The DNA vaccine elicited strong immunogenicity and promoted parasite load reduction in liver and spleen.

To test those vaccines for cutaneous and visceral leishmaniases, BALB/c mice are frequently used for immunological studies. The use of peptides in vaccine composition seems to be promising and has shown interesting results regarding the immune response (Tables 1 and 2). Thus, peptides can trigger important markers related to protection against Leishmania sp., such as the development of a strong cellular response by delaytype hypersensitivity, production of important Th1 cytokines (mainly IFN- $\gamma$ ), and in vitro proliferation of specific T-cells. Regarding vaccine potency and efficacy, the studies show that different peptide vaccine approaches can promote reduction of lesion size and parasite load in affected organs such as liver, spleen, bone marrow, and lymph node (Tables 1 and 2). These emphasize the promising field of using peptides in vaccine development for different diseases including leishmaniases $(9,62,63)$. Despite the promising field and novelty of peptidebased vaccines, to date there are not approved peptide vaccine for human or animal use (64).

\section{VACCINE PEPTIDES: NEW PERSPECTIVES}

\section{Chimeric and Polypeptide Vaccines}

Some research groups aiming to develop Leishmania vaccines to prevent the visceral or cutaneous forms of leishmaniases have tested polyproteins containing multiple antigenic epitopes from Leishmania associated with different adjuvants $(65,66)$. The polyprotein KSAC (a fusion protein composed of KMP-11, SMT, A2, and cysteine peptidase B) was shown to be protective in $\mathrm{BALB} / \mathrm{c}$ mice against early lesion development after sand fly challenge with $L$. major, with an approximately 50 -fold reduction in parasite burden after 5 weeks (67). Alves-Silva et al. (68) showed that a chimeric protein containing $\mathrm{CD}^{+}$and $\mathrm{CD}^{+}$T-cell epitopes for $L$. donovani nucleoside hydrolase 36 promotes cross-protection against Leishmania amazonensis challenge in a BALB/c mice model. In a similar study, Martins et al. (69) demonstrated that a chimeric protein, displaying murine and human MHC class I- and II-specific epitopes from four proteins (LiHyp1, LiHyp6, LiHyV, and HRF) identified in an immunoproteomic study of visceral leishmaniasis antigens, was protective against heterologous challenge with L. amazonensis in a murine model. All these vaccines demonstrated strong potential to be used in phase I clinical trials. However, it is important to combine these antigens with approved adjuvants for safe use in humans, although recombinant Leishmania polyproteins, chimeric, and/or polypeptide vaccines show good manufacturing practices and regulatory approval. These studies show the potential of engineering chimeric peptide/protein vaccines.

\section{Nanovaccines}

Recently, nanotechnology has gained attention in vaccine development, as it provides a path for a promising antigen delivery system that can both stabilize vaccine antigens and act as adjuvants. This approach has been intensively implemented in the therapeutic treatment of cancer and infectious diseases (70-72). Nanovaccines consist of nanoscale particles attached or formulated with antigenic components to drive a specific desired immune response (73). The nanoparticles protect the encapsulated antigenic molecules from degradation by allowing sustained release that maximizes exposure to the immune system, by site-specific delivery, and by enhancing the bioavailability of antigens (73-76). Several studies have demonstrated that peptide-based vaccines may benefit from particulate delivery systems that mimic the size and structure of a pathogen, which favors uptake by DCs and enhances the probability of peptide cross-presentation (77-79). Athanasiou et al. (75) observed that chimeric peptide vaccines containing HLA-restricted epitopes of three immunogenic L. infantum proteins (cysteine peptidase A, histone H1, and KMP-11) encapsulated in poly(lactic-co-glycolic) acid nanoparticles with the adjuvant monophosphoryl lipid A induced IL-12 production, promoted allogeneic T-cell proliferation and intracellular production of IFN- $\gamma$ by $\mathrm{CD}^{+}$and $\mathrm{CD} 8^{+}$ T-cell subsets, and thus stimulated significant protection against L. infantum infection. Thus, a suitable biocompatible delivery system with the appropriate adjuvant is an improved approach for the development of a vaccine against several diseases, including visceral leishmaniasis.

\section{EXPERT COMMENTARY AND CONCLUSION}

The leishmaniases have shown an impressive capacity to spread around the world, disclosing a scarcity of effective management of the epidemiology. Although it is already endemic in many continents, due to global warming, these parasitic diseases may spread into new geographic areas. Thus, in our opinion, the best way to prevent this epidemiological scenario is prophylaxis using vaccine immunizations. Therefore, researchers need to discover novel approaches for identifying promising antigens for vaccine development against leishmaniases. "Rational vaccinology" is a driving force in the discovery of specific epitopes to enhance the immune response and capacity of specific immune cells to eliminate Leishmania parasites.

In this review, we note that a solution for this problem could be achieved with the development of new approaches to identify potential immunogenic peptides. We believe that the most promising approach is immunoinformatics, which can be used for computational mining of proteomic/genomic databases of Leishmania. This approach allows for faster and more costefficient peptide vaccine development. The selection of peptides as antigens may provide a safer solution for leishmaniases, as they are able to promote a specific immune response, show better stability, and can be produced at a more reasonable cost, when compared with whole parasite or recombinant protein antigens. One weakness, however, is that they are liable to immune barriers. To prevent this possible problem, researchers must identify new vaccine designs based on different formulation strategies to define which ones can produce a desired immune response. Indeed, many studies have focused on vaccine design 
methodologies, making it possible to create mechanisms to deliver the entire peptide into the immune system (mainly APCs) and thus promoting enhanced peptide immunogenicity. Recently developed techniques for vaccine design, such as polypeptides, chimeric vaccines, the use of adjuvants, cellular vaccination, and nanovaccines, which allow for a combination of nanoparticles and specific peptides, seem to be the future of vaccine development and hopefully will lead to a safe and effective vaccine against leishmaniases.

\section{STATEMENT}

The authors gathered the background information through an extensive literature search relevant to the topic of interest. The first step was to select original research that is described in Tables 1 and 2. In this concern, the authors consulted PubMed database (https://www.ncbi.nlm.nih.gov/pubmed/) to identify critical articles and to track down "landmark" articles. For that, Boolean operators were used to combine search terms in PubMed as follows: "Leishmania AND synthetic vaccine," "Peptide vaccine AND Leishmania," and "Epitope vaccine AND Leishmania" considering a period (since 1990-2017) trying to offer a retrospective of vaccine design based on leishmanial peptides. The searches outcomes were manually curated to exclude review articles and those not versing about peptides. Furthermore, we excluded manuscripts addressing the use of peptides for leishmaniasis serodiagnosis. From the remaining articles, we selected 30 fulltext articles covering almost all the Leishmania species that cause cutaneous and visceral leishmaniases. These articles comprise the use (selection and testing) of peptides for Leishmania vaccine design and development. They address different approaches to

\section{REFERENCES}

1. Davies CR, Kaye P, Croft SL, Sundar S. Leishmaniasis: new approaches to disease control. BMJ (2003) 326(7385):377-82. doi:10.1136/bmj.326.7385.377

2. Alvar J, Velez ID, Bern C, Herrero M, Desjeux P, Cano J, et al. Leishmaniasis worldwide and global estimates of its incidence. PLoS One (2012) 7(5):e35671. doi:10.1371/journal.pone.0035671

3. Global Burden of Disease Study 2013 Collaborators. Global, regional, and national incidence, prevalence, and years lived with disability for 301 acute and chronic diseases and injuries in 188 countries, 1990-2013: a systematic analysis for the global burden of disease study 2013. Lancet (2015) 386(9995):743-800. doi:10.1016/S0140-6736(15)60692-4

4. Desjeux P. Leishmaniasis: current situation and new perspectives. Comp Immunol Microbiol Infect Dis (2004) 27(5):305-18. doi:10.1016/j.cimid. 2004.03.004

5. Maia-Elkhoury AN, Alves WA, Sousa-Gomes ML, Sena JM, Luna EA. Visceral leishmaniasis in Brazil: trends and challenges. Cad Saude Publica (2008) 24(12):2941-7. doi:10.1590/S0102-311X2008001200024

6. Bailey F, Mondragon-Shem K, Hotez P, Ruiz-Postigo JA, Al-Salem W, AcostaSerrano A, et al. A new perspective on cutaneous leishmaniasis - implications for global prevalence and burden of disease estimates. PLoS Negl Trop Dis (2017) 11(8):e0005739. doi:10.1371/journal.pntd.0005739

7. Costa CH, Peters NC, Maruyama SR, de Brito EC Jr, Santos IK. Vaccines for the leishmaniases: proposals for a research agenda. PLoS Negl Trop Dis (2011) 5(3):e943. doi:10.1371/journal.pntd.0000943

8. Mohebali M, Khamesipour A, Mobedi I, Zarei Z, Hashemi-Fesharki R. Double-blind randomized efficacy field trial of alum precipitated autoclaved Leishmania major vaccine mixed with BCG against canine visceral peptide selection, the use of various methods to design peptidebased vaccines and the use of different experimental models (e.g., mice or PBMC from infected patients) to screen and evaluate the efficacy of immunogenic peptides. Moreover, the articles emphasize the classical markers related to immune system activation (e.g., IFN- $\gamma$ production, proliferation of T-lymphocytes after in vitro stimulus) and the capacity of these peptides to reduce the parasite load and lesion in affected organs which are important aspects for a vaccine design to be considered successful.

\section{AUTHOR CONTRIBUTIONS}

All the authors participated with suggestions and the development of this manuscript; RB participated in the selection of studies related to peptide vaccines development against leishmaniasis in the literature. RB, JC, LR, JV, FM, BR, and RA-S participated in drafting the article and/or revising it critically for important intellectual content, and also created the figures and tables. JR, DR, and AR participated in the study conception, critical revision of the article, and supervision.

\section{FUNDING}

The authors acknowledge the Brazilian agencies $\mathrm{CNPq}$ (MCTI/CNPq/CT-BIOTEC-GENOPROT no. 560943/2010-5, MCTI/CNPq/CT-BIOTEC no. 27/2013, 301526/2015-0, and 486618/2013-7), FAPEMIG (PRONEX APQ-01373-14, APQ01661-13, APQ-01158-16, APQ-00483-16, PPP APQ-01008-14, and PPM-00710-15), CAPES, UFOP, UFMG, and FIOCRUZ for financial support. RB, JC, LR, JV, FM, and DR are grateful for CAPES scholarships; AR and JR are also grateful to CNPq for fellowships.

leishmaniasis in Meshkin-Shahr district, I.R. Iran. Vaccine (2004) 22 (29-30):4097-100. doi:10.1016/j.vaccine.2004.03.058

9. Dikhit MR, Kumar A, Das S, Dehury B, Rout AK, Jamal F, et al. Identification of potential MHC class-II-restricted epitopes derived from Leishmania donovani antigens by reverse vaccinology and evaluation of their CD4+ T-cell responsiveness against visceral leishmaniasis. Front Immunol (2017) 8:1763. doi:10.3389/fimmu.2017.01763

10. Kaye PM, Aebischer T. Visceral leishmaniasis: immunology and prospects for a vaccine. Clin Microbiol Infect (2011) 17(10):1462-70. doi:10.1111/j.14690691.2011.03610.x

11. Banerjee A, Bhattacharya P, Dagur PK, Karmakar S, Ismail N, Joshi AB, et al. Live attenuated Leishmania donovani centrin gene-deleted parasites induce IL-23-dependent IL-17-protective immune response against visceral leishmaniasis in a murine model. J Immunol (2018) 200(1):163-76. doi:10.4049/ jimmunol.1700674

12. Modabber F. First generation leishmaniasis vaccines in clinical development: moving, but what next? Curr Opin Anti Infect Investig Drugs (2000) 2:35-9.

13. Giunchetti RC, Correa-Oliveira R, Martins-Filho OA, Teixeira-Carvalho A, Roatt BM, de Oliveira Aguiar-Soares RD, et al. Immunogenicity of a killed Leishmania vaccine with saponin adjuvant in dogs. Vaccine (2007) 25(44):7674-86. doi:10.1016/j.vaccine.2007.08.009

14. Roatt BM, Aguiar-Soares RD, Vitoriano-Souza J, Coura-Vital W, Braga SL, Correa-Oliveira $\mathrm{R}$, et al. Performance of LBSap vaccine after intradermal challenge with $\mathrm{L}$. infantum and saliva of $\mathrm{Lu}$. longipalpis: immunogenicity and parasitological evaluation. PLoS One (2012) 7(11):e49780. doi:10.1371/ journal.pone.0049780

15. Fiuza JA, Santiago Hda C, Selvapandiyan A, Gannavaram S, Ricci ND, Bueno LL, et al. Induction of immunogenicity by live attenuated Leishmania 
donovani centrin deleted parasites in dogs. Vaccine (2013) 31(14):1785-92. doi:10.1016/j.vaccine.2013.01.048

16. Fernandes AP, Costa MMS, Coelho EAF, Michalick MSM, de Freitas E, Melo MN, et al. Protective immunity against challenge with Leishmania (Leishmania) chagasi in beagle dogs vaccinated with recombinant A2 protein. Vaccine (2008) 26(46):5888-95. doi:10.1016/j.vaccine.2008.05.095

17. Carcelen J, Iniesta V, Fernandez-Cotrina J, Serrano F, Parejo JC, Corraliza I, et al. The chimerical multi-component Q protein from Leishmania in the absence of adjuvant protects dogs against an experimental Leishmania infantum infection. Vaccine (2009) 27(43):5964-73. doi:10.1016/j.vaccine.2009.07.069

18. Martin V, Vouldoukis I, Moreno J, McGahie D, Gueguen S, Cuisinier AM. The protective immune response produced in dogs after primary vaccination with the LiESP/QA-21 vaccine (CaniLeish(R)) remains effective against an experimental challenge one year later. Vet Res (2014) 45:69. doi:10.1186/ 1297-9716-45-69

19. Oliva G, Nieto J, Foglia Manzillo V, Cappiello S, Fiorentino E, Di Muccio T, et al. A randomised, double-blind, controlled efficacy trial of the LiESP/QA-21 vaccine in naive dogs exposed to two Leishmania infantum transmission seasons. PLoS Negl Trop Dis (2014) 8(10):e3213. doi:10.1371/journal.pntd. 0003213

20. Rezvan H, Moafi M. An overview on Leishmania vaccines: a narrative review article. Vet Res Forum (2015) 6(1):1-7.

21. Maroof A, Brown N, Smith B, Hodgkinson MR, Maxwell A, Losch FO, et al. Therapeutic vaccination with recombinant adenovirus reduces splenic parasite burden in experimental visceral leishmaniasis. J Infect Dis (2012) 205(5):853-63. doi:10.1093/infdis/jir842

22. Skwarczynski M, Toth I. Peptide-based synthetic vaccines. Chem Sci (2016) 7(2):842-54. doi:10.1039/c5sc03892h

23. Joshi S, Rawat K, Yadav NK, Kumar V, Siddiqi MI, Dube A. Visceral leishmaniasis: advancements in vaccine development via classical and molecular approaches. Front Immunol (2014) 5:380. doi:10.3389/fimmu.2014.00380

24. Das S, Freier A, Boussoffara T, Das S, Oswald D, Losch FO, et al. Modular multiantigen $\mathrm{T}$ cell epitope-enriched DNA vaccine against human leishmaniasis. Sci Transl Med (2014) 6(234):234ra256. doi:10.1126/scitranslmed. 3008222

25. Sachdeva R, Banerjea AC, Malla N, Dubey ML. Immunogenicity and efficacy of single antigen Gp63, polytope and polytopeHSP70 DNA vaccines against visceral leishmaniasis in experimental mouse model. PLoS One (2009) 4(12):e7880. doi:10.1371/journal.pone.0007880

26. Elfaki ME, Khalil EA, De Groot AS, Musa AM, Gutierrez A, Younis BM, et al. Immunogenicity and immune modulatory effects of in silico predicted L. donovani candidate peptide vaccines. Hum Vaccin Immunother (2012) 8(12):1769-74. doi:10.4161/hv.21881

27. Basu R, Roy S, Walden P. HLA class I-restricted T cell epitopes of the kinetoplastid membrane protein-11 presented by Leishmania donovani-infected human macrophages. J Infect Dis (2007) 195(9):1373-80. doi:10.1086/513439

28. Agallou M, Margaroni M, Karagouni E. Cellular vaccination with bone marrow-derived dendritic cells pulsed with a peptide of Leishmania infantum KMP-11 and CpG oligonucleotides induces protection in a murine model of visceral leishmaniasis. Vaccine (2011) 29(31):5053-64. doi:10.1016/j. vaccine.2011.04.089

29. Agallou M, Athanasiou E, Koutsoni O, Dotsika E, Karagouni E. Experimental validation of multi-epitope peptides including promising MHC class I- and II-restricted epitopes of four known Leishmania infantum proteins. Front Immunol (2014) 5:268. doi:10.3389/fimmu.2014.00268

30. Resende DM, Caetano BC, Dutra MS, Penido ML, Abrantes CF, Verly RM, et al. Epitope mapping and protective immunity elicited by adenovirus expressing the Leishmania amastigote specific A2 antigen: correlation with IFN-gamma and cytolytic activity by CD8+ T cells. Vaccine (2008) 26(35):4585-93. doi:10.1016/j.vaccine.2008.05.091

31. Nico D, Claser C, Borja-Cabrera GP, Travassos LR, Palatnik M, Soares IS, et al. Adaptive immunity against Leishmania nucleoside hydrolase maps its c-terminal domain as the target of the $\mathrm{CD} 4+\mathrm{T}$ cell-driven protective response. PLoS Negl Trop Dis (2010) 4(11):e866. doi:10.1371/journal.pntd.0000866

32. Costa LE, Goulart LR, Pereira NC, Lima MI, Duarte MC, Martins VT, et al. Mimotope-based vaccines of Leishmania infantum antigens and their protective efficacy against visceral leishmaniasis. PLoS One (2014) 9(10):e110014. doi:10.1371/journal.pone.0110014
33. Martins VT, Duarte MC, Chavez-Fumagalli MA, Menezes-Souza D, Coelho CS, de Magalhaes-Soares DF, et al. A Leishmania-specific hypothetical protein expressed in both promastigote and amastigote stages of Leishmania infantum employed for the serodiagnosis of, and as a vaccine candidate against, visceral leishmaniasis. Parasit Vectors (2015) 8:363. doi:10.1186/s13071015-0964-5

34. Mahantesh V, Amit A, Dikhit MR, Singh AK, Venkateshwaran T, Das VNR, et al. Immuno-informatics based approaches to identify CD8+ T cell epitopes within the Leishmania donovani 3-ectonucleotidase in cured visceral leishmaniasis subjects. Microbes Infect (2017) 19(6):358-69. doi:10.1016/j. micinf.2017.03.002

35. Yang DM, Rogers MV, Liew FY. Identification and characterization of host-protective T-cell epitopes of a major surface glycoprotein (gp63) from Leishmania major. Immunology (1991) 72(1):3-9.

36. Jardim A, Alexander J, Teh HS, Ou D, Olafson RW. Immunoprotective Leishmania major synthetic T cell epitopes. J Exp Med (1990) 172(2):645-8. doi:10.1084/jem.172.2.645

37. Russo DM, Jardim A, Carvalho EM, Sleath PR, Armitage RJ, Olafson RW, et al. Mapping human T cell epitopes in Leishmania gp63: identification of cross-reactive and species-specific epitopes. J Immunol (1993) 150(10):4713.

38. Frankenburg S, Axelrod O, Kutner S, Greenblatt CL, Klaus SN, Pirak EA, et al. Effective immunization of mice against cutaneous leishmaniasis using an intrinsically adjuvanted synthetic lipopeptide vaccine. Vaccine (1996) 14(9):923-9. doi:10.1016/0264-410X(95)00245-V

39. Spitzer N, Jardim A, Lippert D, Olafson RW. Long-term protection of mice against Leishmania major with a synthetic peptide vaccine. Vaccine (1999) 17(11-12):1298-300. doi:10.1016/S0264-410X(98)00363-6

40. Tsagozis P, Karagouni E, Dotsika E. Dendritic cells pulsed with peptides of gp63 induce differential protection against experimental cutaneous leishmaniasis. Int J Immunopathol Pharmacol (2004) 17(3):343-52. doi:10.1177/ 039463200401700314

41. Rezvan H, Rees R, Ali S. Immunogenicity of MHC class I peptides derived from Leishmania mexicana Gp63 in HLA-A2.1 transgenic (HHDII) and BALB/C mouse models. Iran J Parasitol (2012) 7(4):27-40.

42. Delgado G, Parra-Lopez CA, Vargas LE, Hoya R, Estupinan M, Guzman F, et al. Characterizing cellular immune response to kinetoplastid membrane protein-11 (KMP-11) during Leishmania (Viannia) panamensis infection using dendritic cells (DCs) as antigen presenting cells (APCs). Parasite Immunol (2003) 25(4):199-209. doi:10.1046/j.1365-3024.2003.00626.x

43. Herrera-Najera C, Pina-Aguilar R, Xacur-Garcia F, Ramirez-Sierra MJ, Dumonteil E. Mining the Leishmania genome for novel antigens and vaccine candidates. Proteomics (2009) 9(5):1293-301. doi:10.1002/pmic.200800533

44. Pereira BA, Silva FS, Rebello KM, Marin-Villa M, Traub-Cseko YM, Andrade $\mathrm{TC}$, et al. In silico predicted epitopes from the $\mathrm{COOH}$-terminal extension of cysteine proteinase B inducing distinct immune responses during Leishmania (Leishmania) amazonensis experimental murine infection. BMC Immunol (2011) 12:44. doi:10.1186/1471-2172-12-44

45. Kedzierska K, Curtis JM, Valkenburg SA, Hatton LA, Kiu H, Doherty PC, et al. Induction of protective CD4+ T cell-mediated immunity by a Leishmania peptide delivered in recombinant influenza viruses. PLoS One (2012) 7(3):e33161. doi:10.1371/journal.pone.0033161

46. Souza-Silva F, Pereira BA, Finkelstein LC, Zucolotto V, Caffarena ER, Alves CR. Dynamic identification of $\mathrm{H} 2$ epitopes from Leishmania (Leishmania) amazonensis cysteine proteinase B with potential immune activity during murine infection. J Mol Recognit (2014) 27(2):98-105. doi:10.1002/jmr.2334

47. Seyed N, Zahedifard F, Safaiyan S, Gholami E, Doustdari F, Azadmanesh K, et al. In silico analysis of six known Leishmania major antigens and in vitro evaluation of specific epitopes eliciting HLA-A2 restricted CD8 T cell response. PLoS Negl Trop Dis (2011) 5(9):e1295. doi:10.1371/journal.pntd. 0001295

48. Zandieh M, Kashi T, Taheri T, Zahedifard F, Taslimi Y, Doustdary M, et al. Assessment of protection induced by DNA and live vaccine encoding Leishmania MHC class I restricted epitopes against L. major challenge in Balb/c mice model. Microb Biochem Technol (2015) 7:427-38. doi:10.4172/ 1948-5948.1000250

49. Costa LE, Chavez-Fumagalli MA, Martins VT, Duarte MC, Lage DP, Lima MI, et al. Phage-fused epitopes from Leishmania infantum used as immunogenic 
vaccines confer partial protection against Leishmania amazonensis infection. Parasitology (2015) 142(10):1335-47. doi:10.1017/S0031182015000724

50. Duarte A, Queiroz AT, Tosta R, Carvalho AM, Barbosa CH, Bellio M, et al. Prediction of $\mathrm{CD} 8+$ epitopes in Leishmania braziliensis proteins using EPIBOT: in silico search and in vivo validation. PLoS One (2015) 10(4):e0124786. doi:10.1371/journal.pone. 0124786

51. Naouar I, Boussoffara T, Chenik M, Gritli S, Ben Ahmed M, Belhadj Hmida N, et al. Prediction of T cell epitopes from Leishmania major potentially excreted/ secreted proteins inducing granzyme B production. PLoS One (2016) 11(1):e0147076. doi:10.1371/journal.pone.0147076

52. Rhaiem RB, Houimel M. Targeting Leishmania major parasite with peptides derived from a combinatorial phage display library. Acta Trop (2016) 159:11-9. doi:10.1016/j.actatropica.2016.03.018

53. Freitas e Silva R, Ferreira LF, Hernandes MZ, de Brito ME, de Oliveira BC, da Silva AA, et al. Combination of in silico methods in the search for potential CD4(+) and CD8(+) T cell epitopes in the proteome of Leishmania braziliensis. Front Immunol (2016) 7:327. doi:10.3389/fimmu.2016.00327

54. Reed SG, Orr MT, Fox CB. Key roles of adjuvants in modern vaccines. Nat Med (2013) 19(12):1597-608. doi:10.1038/nm.3409

55. Brusic V, Petrovsky N. Immunoinformatics and its relevance to understanding human immune disease. Expert Rev Clin Immunol (2005) 1(1):145-57. doi:10.1586/1744666X.1.1.145

56. Bambini S, Rappuoli R. The use of genomics in microbial vaccine development. Drug Discov Today (2009) 14(5-6):252-60. doi:10.1016/j.drudis. 2008.12.007

57. Resende DM, Rezende AM, Oliveira NJ, Batista IC, Correa-Oliveira R, Reis AB, et al. An assessment on epitope prediction methods for protozoa genomes. BMC Bioinformatics (2012) 13:309. doi:10.1186/1471-2105-13-309

58. Brito RCF, Guimaraes FG, Velloso JP, Correa-Oliveira R, Ruiz JC, Reis AB, et al. Immunoinformatics features linked to Leishmania vaccine development: data integration of experimental and in silico studies. Int J Mol Sci (2017) 18(2):E371. doi:10.3390/ijms18020371

59. Smith GP, Petrenko VA. Phage display. Chem Rev (1997) 97(2):391-410. doi:10.1021/cr960065d

60. Pini A, Giuliani A, Falciani C, Runci Y, Ricci C, Lelli B, et al. Antimicrobial activity of novel dendrimeric peptides obtained by phage display selection and rational modification. Antimicrob Agents Chemother (2005) 49(7): 2665-72. doi:10.1128/AAC.49.7.2665-2672.2005

61. Courret N, Prina E, Mougneau E, Saraiva EM, Sacks DL, Glaichenhaus N, et al. Presentation of the Leishmania antigen LACK by infected macrophages is dependent upon the virulence of the phagocytosed parasites. Eur J Immunol (1999) 29(3):762-73. doi:10.1002/(SICI)1521-4141(199903) 29:03<762::AID-IMMU762>3.0.CO;2-4

62. Amit A, Dikhit MR, Mahantesh V, Chaudhary R, Singh AK, Singh A, et al. Immunomodulation mediated through Leishmania donovani protein disulfide isomerase by eliciting CD8+ T-cell in cured visceral leishmaniasis subjects and identification of its possible HLA class-1 restricted T-cell epitopes. J Biomol Struct Dyn (2017) 35(1):128-40. doi:10.1080/07391102. 2015.1134349

63. Dikhit MR, Mahantesh V, Kumar A, Amit A, Dehury B, Nathsharma YP, et al. Mining the proteome of Leishmania donovani for the development of novel MHC class I restricted epitope for the control of visceral leishmaniasis. J Cell Biochem (2018) 119(1):378-91. doi:10.1002/jcb.26190

64. Yang H, Kim DS. Peptide immunotherapy in vaccine development: from epitope to adjuvant. Adv Protein Chem Struct Biol (2015) 99:1-14. doi:10.1016/ bs.apcsb.2015.03.001

65. Bertholet S, Goto Y, Carter L, Bhatia A, Howard RF, Carter D, et al. Optimized subunit vaccine protects against experimental leishmaniasis. Vaccine (2009) 27(50):7036-45. doi:10.1016/j.vaccine.2009.09.066

66. Goto Y, Bhatia A, Raman VS, Liang H, Mohamath R, Picone AF, et al. KSAC, the first defined polyprotein vaccine candidate for visceral leishmaniasis. Clin Vaccine Immunol (2011) 18(7):1118-24. doi:10.1128/CVI.05024-11
67. Gomes R, Teixeira C, Oliveira F, Lawyer PG, Elnaiem DE, Meneses C, et al. KSAC, a defined Leishmania antigen, plus adjuvant protects against the virulence of $L$. major transmitted by its natural vector Phlebotomus duboscqi. PLoS Negl Trop Dis (2012) 6(4):e1610. doi:10.1371/journal. pntd.0001610

68. Alves-Silva MV, Nico D, Morrot A, Palatnik M, Palatnik-de-Sousa CB. A chimera containing CD4+ and CD8+ T-cell epitopes of the Leishmania donovani nucleoside hydrolase (NH36) optimizes cross-protection against Leishmania amazonensis infection. Front Immunol (2017) 8:100. doi:10.3389/ fimmu.2017.00100

69. Martins VT, Lage DP, Duarte MC, Carvalho AM, Costa LE, Mendes TA, et al. A recombinant fusion protein displaying murine and human MHC class I- and II-specific epitopes protects against Leishmania amazonensis infection. Cell Immunol (2017) 313:32-42. doi:10.1016/j.cellimm.2016.12.008

70. Stern ST, McNeil SE. Nanotechnology safety concerns revisited. Toxicol Sci (2008) 101(1):4-21. doi:10.1093/toxsci/kfm 169

71. Moon JJ, Suh H, Bershteyn A, Stephan MT, Liu H, Huang B, et al. Interbilayer-crosslinked multilamellar vesicles as synthetic vaccines for potent humoral and cellular immune responses. Nat Mater (2011) 10(3): 243-51. doi:10.1038/nmat2960

72. Gregory AE, Titball R, Williamson D. Vaccine delivery using nanoparticles. Front Cell Infect Microbiol (2013) 3:13. doi:10.3389/fcimb.2013.00013

73. Zaman M, Good MF, Toth I. Nanovaccines and their mode of action. Methods (2013) 60(3):226-31. doi:10.1016/j.ymeth.2013.04.014

74. Zolnik BS, Gonzalez-Fernandez A, Sadrieh N, Dobrovolskaia MA. Nanoparticles and the immune system. Endocrinology (2010) 151(2):458-65. doi:10.1210/en.2009-1082

75. Athanasiou E, Agallou M, Tastsoglou S, Kammona O, Hatzigeorgiou A, Kiparissides C, et al. A poly(lactic-co-glycolic) acid nanovaccine based on chimeric peptides from different Leishmania infantum proteins induces dendritic cells maturation and promotes peptide-specific IFN gamma-producing $\mathrm{CD} 8(+) \mathrm{T}$ cells essential for the protection against experimental visceral leishmaniasis. Front Immunol (2017) 8:684. doi:10.3389/ fimmu.2017.00684

76. Chow A, Stuckey DJ, Kidher E, Rocco M, Jabbour RJ, Mansfield CA, et al. Human induced pluripotent stem cell-derived cardiomyocyte encapsulating bioactive hydrogels improve rat heart function post myocardial infarction. Stem Cell Reports (2017) 9(5):1415-22. doi:10.1016/j.stemcr.2017.09.003

77. Panda AK. Induction of anti-tumor immunity and T-cell responses using nanodelivery systems engrafting TLR-5 ligand. Expert Rev Vaccines (2011) 10(2):155-7. doi:10.1586/erv.10.164

78. Joshi MD, Unger WJ, Storm G, van Kooyk Y, Mastrobattista E. Targeting tumor antigens to dendritic cells using particulate carriers. J Control Release (2012) 161(1):25-37. doi:10.1016/j.jconrel.2012.05.010

79. Varypataki EM, Silva AL, Barnier-Quer C, Collin N, Ossendorp F, Jiskoot W. Synthetic long peptide-based vaccine formulations for induction of cell mediated immunity: a comparative study of cationic liposomes and PLGA nanoparticles. J Control Release (2016) 226:98-106. doi:10.1016/j.jconrel. 2016.02.018

Conflict of Interest Statement: The authors declare that the research was conducted in the absence of any commercial or financial relationships that could be construed as a potential conflict of interest.

Copyright $\odot 2018$ De Brito, Cardoso, Reis, Vieira, Mathias, Roatt, Aguiar-Soares, Ruiz, Resende and Reis. This is an open-access article distributed under the terms of the Creative Commons Attribution License (CC BY). The use, distribution or reproduction in other forums is permitted, provided the original author(s) and the copyright owner are credited and that the original publication in this journal is cited, in accordance with accepted academic practice. No use, distribution or reproduction is permitted which does not comply with these terms. 